UDC 636.2.034

COBISS.SR-ID 250157068

Original research paper

Acta Agriculturae Serbica, Vol. XXII, 43 (2017); 23-35

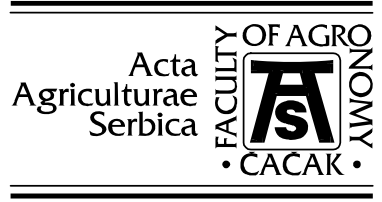

\title{
The effect of systematic factors on $4 \%$ fat-corrected milk yield in Simmental cows
}

\author{
Milun D. Petrović ${ }^{1}$, Vladan Bogdanović ${ }^{2}$, Snežana Bogosavljević-Bošković ${ }^{1}$, \\ Radojica Đoković ${ }^{1}$, Simeon Rakonjac ${ }^{1}$, Miloš Ži. Petrović ${ }^{1}$, Vladimir \\ Doskovic $^{1}$ \\ ${ }^{1}$ University of Kragujevac, Faculty of Agronomy, Čačak, Serbia \\ ${ }^{2}$ University of Belgrade, Faculty og Agriculture, Zemun, Serbia \\ Corresponding author: milunp@kg.ac.rs
}

\begin{abstract}
The effect of systematic and continuous environmental factors on $4 \%$ fatcorrected milk (FCM) yield in 2805 Simmental cows over whole and standard lactations was evaluated using the general linear model. The test systematic or fixed factors included the effect of farm or breeding area, calving season, year of birth, season of birth, lactation group and interactions between year of birth and season of birth, breeding area and calving season, and breeding area and lactation group. The continuous factor analysed was the effect of age at first conception.

The effect of breeding area, lactation group and calving season on 4\%FCM yield over whole and standard lactations was found to be very highly significant $(\mathrm{P}<0.001)$.

The interactions of fixed i.e. systematic factors involved in the model, including those between year and season of birth, breeding area and calving season, and farm and lactation group had a very highly significant effect $(\mathrm{P}<0.001)$ on $4 \%$ FCM yield over both whole and standard lactations.

The age at first conception, as a continuous factor, showed a very highly significant effect $(\mathrm{P}<0.001)$ on $4 \%$ FCM yield over both whole and standard lactations.

The model used to correct the $4 \% \mathrm{FCM}$ yield over whole and standard lactations for the effect of systematic factors was very highly significant $(\mathrm{P}<0.001)$. The variance of the model accounted for $15.93 \%$ and $21.55 \%$ of the total variance in $4 \% \mathrm{FCM}$ yield over whole and standard lactations, respectively. The resulting coefficient of determination $\left(\mathrm{R}^{2}\right)$ in $4 \% \mathrm{FCM}$ yield was 0.159 over whole lactations and 0.216 over standard lactations.
\end{abstract}

Received 12 April 2017 Accepted 4 September 2017 
Key words: Simmental breed, 4\% fat-corrected milk, systematic effects, coefficient of determination.

\section{Introduction}

Given the fact that milk production is a polygenic quantitative trait dependent upon genotype (25\%) and non-genetic factors $(75 \%)$, its variability is extremely high. Studies on phenotypic and genetic variability of production traits are of high practical importance in that variability underlies selection effects across years and generations.

The cattle breeding procedures used today most commonly employ linear methods and models that combine fixed parameters (year, farm, season, lactation) and random variables (regression effect, random variables effect) which can be mutually dependent (related) or independent, with or without interactions, depending on the trait analysed. The selected model results essentially in the breeding value of an individual animal (Bogdanović et al., 2003).

Depending on the level of production, sample size and mathematical statistical model, non-genetic discontinuous factors (year, farm, season, lactation) can account for as much as above $50 \%$ of the total variations in milk production (Stojić et al., 1996). The same authors, Stojić et al. (1995), reported that farm, year and season of calving induced $35.7 \%$ of total variations in milk production. A somewhat lower percentage of non-genetic factors (farm, year, calving season and lactation number) of $22.7 \%$ in the total variability of production traits was found by Jovanovac (1987), whereas Hansen et al. (1983) reported a considerably higher percentage of about $45 \%$ (in terms of the farm-year-season effect).

Most authors agree that milk and fat yields over whole and standard lactations increase with advancing age at first conception (Fiss and Wilton 1989, Michel et al., 1989, Perišić 2002).

A thorough analysis of production traits in cows requires determination of the milk performance of dairy cattle based on yields of milk corrected to $4.0 \%$ fat, and evaluation of the effect of non-genetic factors on the trait.

\section{Material and methods}

\section{Material}

This study on the effect of systematic factors on $4 \%$ fat-corrected milk yield over whole and standard lactations involved 2805 Simmental cows housed on three farms i.e. in three different breeding areas, including the following: 
-"Zlatiborski Suvati" dairy farm on Mt. Zlatibor, employing a free-stall housing system with lying and resting boxes (lige boxen), located at about $1000 \mathrm{~m}$ a.s.1. $(\mathrm{n}=578)$,

- Dobričevo dairy farm in the lowlands in Ćuprija, using tie-stall housing $(\mathrm{n}=964)$, and

- individual tie-stall farms in the Kotraže region, located at $400-700 \mathrm{~m}$ a.s.1. $(n=1263)$.

The traits analysed

The following production traits were analysed:

- 4\% fat-corrected milk yield over whole lactations (4\%FCMWL), $(\mathrm{kg})$ and

- 4\% fat-corrected milk yield over standard lactations (4\%FCMSL), $(\mathrm{kg})$.

\section{Methods}

\section{Data preparation for statistical analysis}

The correction of milk yield for the fat content of $4 \%(4 \% \mathrm{FCM})$ over whole and standard lactations was made using the following Gaines-Davidson formula:

$$
4 \% F C M=0.4 M+15 F
$$

$\mathrm{M}$ - amount of milk (kg)

$\mathrm{F}$ - amount of milk fat $(\mathrm{kg})$

\section{Systematic environmental factors}

The yield of $4 \%$ fat-corrected milk over whole and standard lactations was affected by the following systematic factors tested in this study:

o Breeding area. The effect of three farm locations was studied (the farm on Mt. Zlatibor, Dobričevo farm and farms in the Kotraža region).

o Lactation groups. Lactation groups were established in order to equalize the number of animals within different lactations as much as possible and reduce variability:

- Group I (first lactation),

- Group II (second lactation),

- Group III (third lactation),

- Group IV (fourth lactation),

- Group V (fifth lactation),

- Group VI (sixth and other lactations), 
o Calving season, i.e. the onset of lactation (I-spring season (March through May), IIsummer season (June through August), III-autumn season (September through November), IV-winter season (December through February)).

o Year of birth $\mathbf{x}$ season of birth interaction (cows that calved from 1982 to $1998 \mathrm{x}$ 4 seasons (I-spring, II-summer, III-autumn and IV-winter seasons)).

0 Breeding area $x$ calving season interaction (3 breeding areas $x 4$ calving seasons).

o Breeding area $\mathbf{x}$ lactation group interaction (3 breeding areas $\mathrm{x} 6$ lactation groups).

\section{o Linear regression effect}

Table 1. Presentation of data across different classes of major systematic effects

\begin{tabular}{|c|c|c|c|c|c|c|c|c|c|c|}
\hline Farm & $\begin{array}{l}\text { Lact. } \\
\text { No. }\end{array}$ & $\begin{array}{l}\text { Cow } \\
\text { No. }\end{array}$ & $\begin{array}{l}\text { Lactation } \\
\text { group }\end{array}$ & $\begin{array}{l}\text { Lact. } \\
\text { No. }\end{array}$ & $\begin{array}{c}\text { Year } \\
\text { of } \\
\text { birth }\end{array}$ & $\begin{array}{l}\text { Lact. } \\
\text { No. }\end{array}$ & $\begin{array}{l}\text { Season } \\
\text { of birth }\end{array}$ & $\begin{array}{l}\text { Lact. } \\
\text { No. }\end{array}$ & $\begin{array}{c}\text { Season } \\
\text { of } \\
\text { calving }\end{array}$ & $\begin{array}{l}\text { Lact. } \\
\text { No. }\end{array}$ \\
\hline \multirow{2}{*}{$\begin{array}{c}\mathrm{I} \\
\text { (Zlatibor) }\end{array}$} & \multirow{2}{*}{1968} & \multirow{2}{*}{578} & I (1) & 2800 & 1982 & 847 & I & 2298 & I & 2281 \\
\hline & & & II (2) & 2297 & 1983 & 565 & II & 2837 & II & 2642 \\
\hline \multirow{2}{*}{$\frac{\text { II }}{(\text { Dobričevo) }}$} & \multirow{2}{*}{3237} & \multirow{2}{*}{964} & III (3) & 1715 & 1984 & 624 & III & 2035 & III & 2269 \\
\hline & & & IV(4) & 1213 & 1985 & 541 & IV & 2552 & IV & 2526 \\
\hline \multirow{2}{*}{$\begin{array}{c}\text { III } \\
\text { (Kotraža) }\end{array}$} & \multirow{2}{*}{4513} & \multirow{2}{*}{1263} & $V(5)$ & $\begin{array}{l}799 \\
894\end{array}$ & 1986 & 855 & & & & \\
\hline & & & \multirow{2}{*}{$\begin{array}{l}\mathrm{VI}(6+7+8+9 \\
+10+11+12)\end{array}$} & \multirow{2}{*}{894} & 1987 & 822 & & & & \\
\hline & & & & & 1988 & 791 & & & & \\
\hline & & & & & 1989 & 839 & & & & \\
\hline & & & & & 1990 & 786 & & & & \\
\hline & & & & & 1991 & 627 & & & & \\
\hline & & & & & 1992 & 612 & & & & \\
\hline & & & & & 1993 & 306 & & & & \\
\hline & & & & & 1994 & 467 & & & & \\
\hline & & & & & 1995 & 516 & & & & \\
\hline & & & & & 1996 & 342 & & & & \\
\hline & & & & & 1997 & 76 & & & & \\
\hline & & & & & 1998 & 102 & & & & \\
\hline
\end{tabular}

\section{Evaluation of systematic environmental effects}

The effect of systematic environmental factors was analysed by the GLM (general linear model) using the statistical software Statistica for Windows Release 6.0. (StatSoft, 1995). This procedure enables simultaneous analysis of a number of different effects, regardless of their being either categorical or continuous factors by nature. To estimate effects and test hypotheses, the least squares method is used to fit the general linear model.

The effect of non-genetic factors on $4 \%$ fat-corrected milk yield over whole 
and standard lactations was analysed according to the following model:

$$
\mathrm{y}_{\mathrm{ijkl}}=\mu+\mathrm{B}_{\mathrm{i}}+\mathrm{L}_{\mathrm{j}}+\mathrm{G}_{\mathrm{k}}+\mathrm{Cs}_{\mathrm{l}}+\mathrm{BCs}_{\mathrm{il}}+\mathrm{BL}_{\mathrm{ij}}+\mathrm{b}_{1}\left(\mathrm{x}_{1}-\bar{X}_{1}\right)+\mathrm{e}_{\mathrm{ijk} \mathrm{k}} \text {, where: }
$$

$\mathrm{y}_{\mathrm{ijkl}}$ - an individual animal of the $\mathrm{i}$-th breeding area, $\mathrm{j}$-th lactation group, $\mathrm{k}$-th group, 1-th calving season,

$\mu-$ population mean with equal participation of all classes of effects $(B, L$, $\mathrm{G}, \mathrm{Cs}, \mathrm{BCs}, \mathrm{BL})$,

$B_{i}$ - fixed effect of the $i$-th breeding area (1-3),

$\mathrm{L}_{\mathrm{j}}$ - fixed effect of the $\mathrm{j}$-th lactation group (1-6),

$\mathrm{G}_{\mathrm{k}}$ - fixed effect of the k-th group (year of birth x season of birth) (1-68),

$\mathrm{Cs}_{1}-$ fixed effect of the 1-th calving season (1-4),

$\mathrm{BCs}_{\mathrm{il}}$ - fixed effect of the $\mathrm{i}$-th breeding area $\mathrm{x}$ 1-th calving season interaction (112), $18)$,

$\mathrm{BL}_{\mathrm{ij}}$ - fixed effect of the $\mathrm{i}$-th breeding area $\mathrm{x} \mathrm{j}$-th lactation group interaction (1-

$b_{1}$ - linear regression coefficient of the effect of age at first conception, and

$\mathrm{e}_{\mathrm{ijkl}}-$ other undetermined effects.

As part of further analysis of $4 \%$ fat-corrected milk yield over whole and standard lactations, presented below are the results of the analysis of variance, including the significance of test factors, sum of squares, and \% of the total sum, as well as the coefficients of determination $\left(\mathrm{R}^{2}\right)$ which denote the residual of the variance i.e. the model variance divided by 100 .

\section{Results and discussion}

Table 2. outlines the results on the effect of systematic factors on $4 \%$ fatcorrected milk yield over whole and standard lactations, including least squares means (LSM), standard errors of the means $\left(\mathrm{SE}_{\mathrm{LSM}}\right)$ and significance of the effects analysed.

The table 2 shows a very high significant effect of the systematic factors along with calving season on 4\%FCM yield over whole and standard lactations, which suggests the necessity to correct the yield for the effect of the systematic factors analysed.

The effect of breeding area on $4 \%$ fat-corrected milk yield over whole and standard lactations was very highly significant $(\mathrm{P}<0.001)$. The high intensity of the production technology used on the Zlatibor and Dobričevo farms resulted in a higher 4\% FCM yield as compared to individual farms in the Kotraže region. The cows on the Zlatiborski Suvati farm gave the highest yield of 4\% FCM, which was attributable to the more favourable effect of free-stall housing system on production traits as compared to the tie-stall system employed on the Dobričevo farm. Most authors report significant and very significant effects of farm on milk, 
fat and 4\% FCM yields (Petrović et al., 1997 and 2006, Perišić 1998, Rychen 1999, Chladek and Kucera 2000, Đurđević 2001, Đurđević et al., 2002, Panić 2005, Petrović D.M. et al., 2016).

Table 2. Least squares means (LSM), standard errors ( $\left.\mathrm{SE}_{\mathrm{LSM}}\right)$ of the means and significance of the effect of systematic factors and age at first conception on $4 \%$ FCM yield over whole and standard lactations

\begin{tabular}{|c|c|c|c|c|c|}
\hline \multirow{3}{*}{$\begin{array}{c}\begin{array}{c}\text { Systematic } \\
\text { effects }\end{array} \\
\text { Farm }\end{array}$} & \multicolumn{5}{|c|}{ Milk production traits } \\
\hline & \multirow{2}{*}{$\mathrm{N}$} & \multicolumn{2}{|c|}{$\begin{array}{c}\text { 4\%FCMWL } \\
(\mathrm{kg})\end{array}$} & \multicolumn{2}{|c|}{$\begin{array}{c}\text { 4\%FCMSL } \\
(\mathrm{kg})\end{array}$} \\
\hline & & LSM & $\mathrm{SE}_{\mathrm{LSM}}$ & LSM & $\mathrm{SE}_{\mathrm{LSM}}$ \\
\hline I & 1968 & 4333.7 & 29.81 & 4132.2 & 21.27 \\
\hline II & 3237 & 3763.4 & 25.77 & 3922.9 & 18.39 \\
\hline III & 4513 & 3773.4 & 22.02 & 3911.1 & 15.71 \\
\hline \multicolumn{2}{|l|}{$F_{\exp }$} & \multicolumn{2}{|c|}{$183.42^{* * *}$} & \multicolumn{2}{|c|}{$52.89^{* * *}$} \\
\hline \multicolumn{6}{|l|}{ Calving season } \\
\hline I & 2281 & 3968.5 & 28.70 & 4004.0 & 20.49 \\
\hline II & 2642 & 3869.6 & 26.80 & 3875.8 & 19.13 \\
\hline III & 2269 & 3999.6 & 26.04 & 4016.5 & 18.59 \\
\hline IV & 2526 & 3989.7 & 25.86 & 4058.8 & 18.46 \\
\hline \multicolumn{2}{|l|}{$\mathrm{F}_{\exp }$} & \multicolumn{2}{|c|}{$7.32^{* * *}$} & \multicolumn{2}{|c|}{$25.47^{* * *}$} \\
\hline \multicolumn{6}{|l|}{ Lactation group } \\
\hline I (1) & 2800 & 3685.5 & 23.27 & 3613.6 & 16.61 \\
\hline II (2) & 2297 & 3905.3 & 25.86 & 3926.9 & 18.46 \\
\hline III (3) & 1715 & 4067.8 & 29.56 & 4091.8 & 21.10 \\
\hline IV (4) & 1213 & 4083.6 & 34.25 & 4154.1 & 24.44 \\
\hline $\mathrm{V}(5)$ & 799 & 4070.7 & 40.55 & 4143.5 & 28.94 \\
\hline VI (6 and onwards) & 894 & 3928.2 & 39.85 & 4002.8 & 28.44 \\
\hline \multicolumn{2}{|l|}{$\mathrm{F}_{\exp }$} & \multicolumn{2}{|c|}{$41.48^{* * *}$} & \multicolumn{2}{|c|}{$143.03^{* * *}$} \\
\hline \multicolumn{6}{|c|}{$\begin{array}{c}\text { Group (Yr of birth } x \text { Season of } \\
\text { birth) }\end{array}$} \\
\hline \multicolumn{2}{|c|}{$\mathrm{F}_{\exp }$} & \multicolumn{2}{|c|}{$5.60^{* * *}$} & \multicolumn{2}{|c|}{$5.95^{* * *}$} \\
\hline \multicolumn{6}{|c|}{ Farm x Calving season } \\
\hline \multicolumn{2}{|c|}{$\mathrm{F}_{\exp }$} & \multicolumn{2}{|c|}{$7.43^{* * *}$} & \multicolumn{2}{|c|}{$9.71^{* * *}$} \\
\hline \multicolumn{6}{|c|}{ Farm x Lactation group } \\
\hline \multicolumn{2}{|c|}{$\mathrm{F}_{\exp }$} & \multicolumn{2}{|c|}{$35.95^{* * *}$} & \multicolumn{2}{|c|}{$50.14^{* * *}$} \\
\hline \multicolumn{6}{|c|}{ Age at $1^{\text {st }}$ conception } \\
\hline \multicolumn{2}{|l|}{$\mathrm{F}_{\text {exp }}$} & \multicolumn{2}{|c|}{$14.14^{* * *}$} & \multicolumn{2}{|c|}{$28.29^{* * *}$} \\
\hline
\end{tabular}


Calving season had a very highly significant effect $(\mathrm{P}<0.001)$ on $4 \%$ fatcorrected milk yield over both whole and standard lactations, primarily through the types of roughage used in the diet (green forage or dry roughage) and temperature. The lowest yield of $4 \% \mathrm{FCM}$, as induced by the unfavourable effect of high temperatures, was obtained in the summer season, whereas the yield during the other three seasons (autumn, winter and spring seasons) was almost identical. Accordingly, the effect of calving season should be included in the model used to estimate the breeding value of dairy cows. Most authors (Petrović M.M. et al., 1997, Saveli 1997, Perišić 1998, Kučera et al., 1999, Rychen 1999, Đurđević 2001, Gaydarska et al., 2001, Singh et al., 2002, Petrović D.M. et al., 2005, 2006 and 2010, Panić 2005) report significant, very significant and very highly significant effects of calving season on milk production, as opposed to Chladek and Kucera (2000), Pantelić et al. (2005), and Petrović D.M et al. (2016), who found a nonsignificant effect of $(\mathrm{P}>0.05)$ the factor analysed.

The effect of lactation number on $4 \%$ fat-corrected milk yield over whole and standard lactations was very highly significant $(\mathrm{P}<0.001)$. The yield was lowest in the first whole and standard lactations $(\mathrm{LSM}=3685.5 \mathrm{~kg}$ and $\mathrm{LSM}=3613.6 \mathrm{~kg}$, respectively), and highest in the fourth lactation (LSM=4083.6 $\mathrm{kg}$ and $\mathrm{LSM}=$ $4154.1 \mathrm{~kg}$, respectively). Highly significant and very highly significant effects of lactation number on the yield of non-corrected and 4\% fat-corrected milk over both whole and standard lactations were reported by most authors (Perišić 1998, Rychen 1999, Đurđević 2001, Gaydarska et al., 2001, Petrović D.M. et al., 2005, 2006, 2010 and 2016, Pantelić et al., 2005 and Panić 2005).

Group defined as the year of birth $\mathrm{x}$ season of birth, farm $\mathrm{x}$ calving season and farm $x$ lactation group interactions exhibited a very highly significant effect $(\mathrm{P}<0.001)$ on $4 \%$ fat-corrected milk yield over whole and standard lactations. Therefore, the inclusion of both the above individual systematic factors and their interactions into the models used to estimate the breeding value of cows was found to be justified. Stojic (1996) determined that the effect of farm-year-season was the most dominant effect for all milk production parameters analysed $(\mathrm{P}<0.01)$. A study conducted by Petrović M.M. et al. (1997), on active Simmental cattle population in Serbia suggested that the breeding area $\mathrm{x}$ calving season interaction contributed to highly significant variations in milk yield $(\mathrm{P}<0.01)$.

Age at first conception, as a continuous factor, had a statistically very highly significant $(\mathrm{P}<0.001)$ effect on $4 \%$ fat-corrected milk yield over both whole and standard lactations. Lin et al. (1988) and Perišić et al. (2002) reported significant $(\mathrm{P}<0.05)$ and very significant $(\mathrm{P}<0.01)$ effects of age at first conception, as a fixed factor, on the first lactation production traits, with the effect being further lost, resulting in a non-significant effect of age at first conception on milk production in the second and third lactations. A non-significant $(\mathrm{P}>0.05)$ random effect of age at first conception on milk production traits was observed by Đurđević (2001), Đurđević et al. (2002) and Petrović D.M. et al. (2006).

The significance of systematic effects and age at first conception on $4 \%$ fat- 
corrected milk yield over whole and standard lactations, the sum of squares of individual effects, the model and residual variance used and their percentage of the total sum of squares, and coefficients of determination $\left(\mathrm{R}^{2}\right)$ are presented in Table 3.

Table 3. Analysis of variance for milk production traits in standard lactations.

Significance of factors, sums of squares, $\%$ of the total sum and coefficients of determination $\left(\mathrm{R}^{2}\right)$

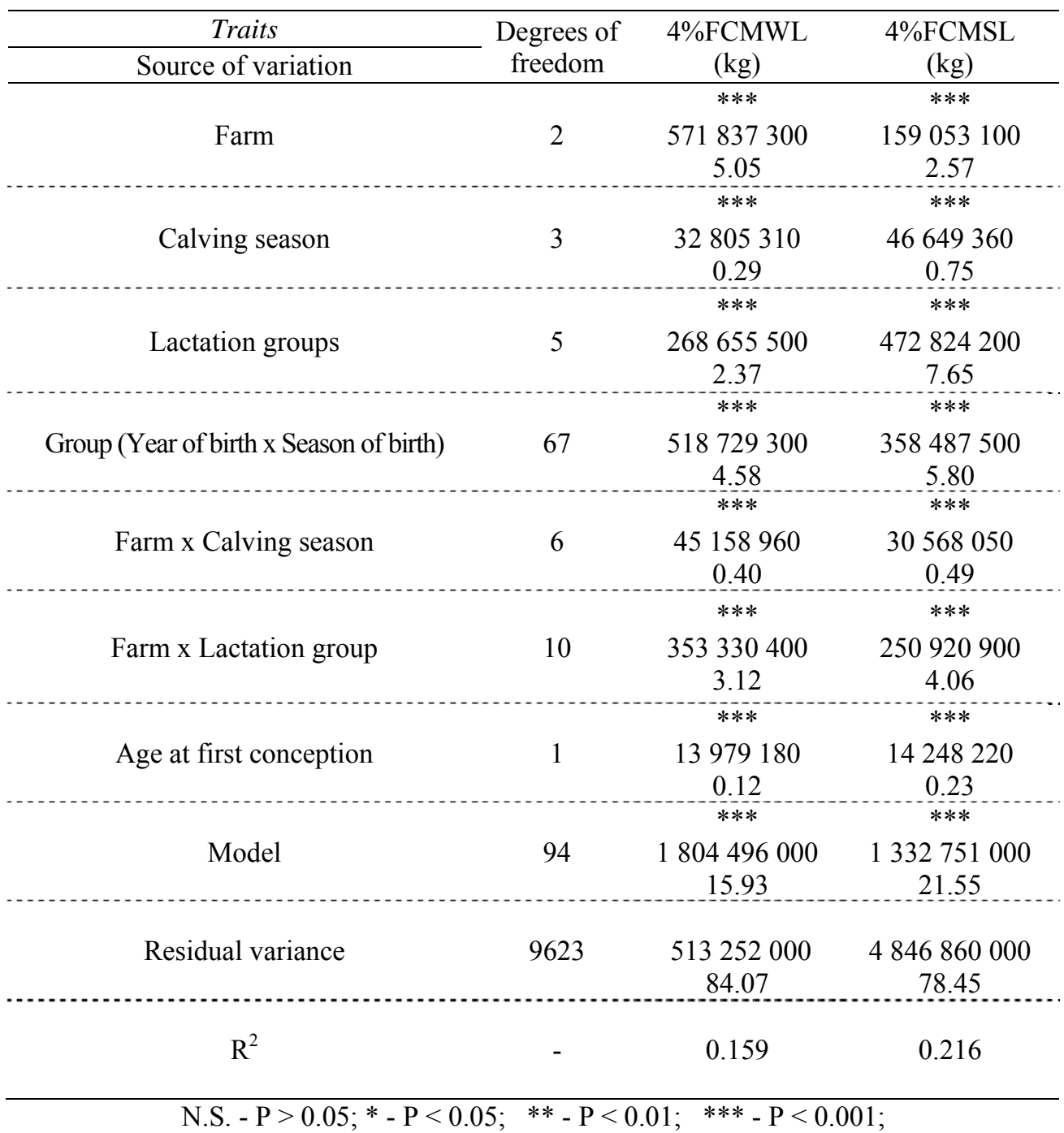


The percent contribution of the tested continuous and discontinuous systematic factors and their interactions to the total variability of the traits analysed ranged from $15.93 \%$ to $21.55 \%$ in $4 \% \mathrm{FCM}$ yield over whole and standard lactations, respectively, denoting the variance of the model used. The highest percent contribution to the model variance in $4 \% \mathrm{FCM}$ yield over whole lactations and standard lactations was accounted for by the effect of breeding area $(5.05 \%)$ and lactation group i.e. lactation number $(7.65 \%)$, respectively. Among the non-genetic factors analysed, the lowest variability in 4\%FCM yield was caused by age at first conception, accounting for as low as $0.12 \%$ and $0.23 \%$ of the model variance in whole and standard lactations, respectively. The very low percent contribution of the variance of age at first conception to the total variance of the model - below $0.5 \%$, in $4 \%$ FCM yield over whole and standard lactations was reported by Petrović D.M. et al. (2005, 2006 and 2010). Calving season also accounted for a low percentage (below 1\%) in the total variance of the model for 4\% FCM yield over whole lactations $(0.29 \%)$ and standard lactations $(0.75 \%)$. A higher percent contribution of the calving season variance to the total variability of production traits was found by Mchau and Syrstad (1991). Milk production control in Norway suggested that month of calving made up $2-3 \%$ of the total variability of production traits.

The model used to correct milk yield to $4 \%$ fat-corrected milk over whole and standard lactations for the effect of systematic factors and their individual interactions was very highly significant $(\mathrm{P}<0.001)$, suggesting adequate selection of the systematic factors included in the model and the necessity to correct production traits for their effect.

The calculated coefficients of determination, indicating the level of variation in $4 \% \mathrm{FCM}$ that can be explained by the model used, ranged from 0.159 in $4 \% \mathrm{FCM}$ over whole lactations to $0.216 \%$ over standard lactations. In their 2010 and 2016 study, the same authors Petrović D.M. et al (2010. and 2016) obtained somewhat higher values for the coefficients of determination - 0.206 and 0.623 in $4 \% \mathrm{FCMWL}$ to 0.301 and 0.474 in $4 \% \mathrm{FCMSL}$, regardless of the small number of systematic effects included in the model. The low values of the coefficients of determination undoubtedly show that the variability of the traits was affected not only by genetic factors but also by a large number of other non-genetic factors that were not included in the model used in this study, but will be covered by further research. 


\section{Conclusion}

The model used to evaluate the effect of systematic environmental factors, their interactions and cow age at first conception on $4 \%$ fat-corrected milk yield and its variability over whole and standard lactations suggests the following:

- The effect of breeding area, lactation group and calving season on 4\% FCM yield over whole and standard lactations was very highly significant $(\mathrm{P}<0.001)$.

- The interactions between fixed systematic factors included in the model, such as year of birth $\mathrm{x}$ season of birth, farm $\mathrm{x}$ calving season, and farm $\mathrm{x}$ lactation group interactions had a very highly significant $(\mathrm{P}<0.001)$ effect on $4 \%$ FCM yield over both whole and standard lactations.

- Age at first conception as a continuous factor showed a statistically very highly significant $(\mathrm{P}<0.001)$ effect on $4 \%$ fat-corrected milk yield over whole and standard lactations as well as on milk fat content, and a non-significant effect $(\mathrm{P}>0.05)$ on milk fat production.

- The model used to correct 4\% FCM yield over whole and standard lactations for the effect of systematic factors was very highly significant $(\mathrm{P}<0.001)$. The percent contribution of the model variance to the total variance of the traits analysed ranged from $15.93 \%$ in $4 \% \mathrm{FCM}$ over whole lactations to $21.55 \%$ in $4 \% \mathrm{FCM}$ over standard lactations.

- The coefficients of determination $\left(\mathrm{R}^{2}\right)$ obtained by means of the model ranged from 0.159 to 0.216 in $4 \% \mathrm{FCM}$ yield over whole and standard lactations, respectively.

\section{References}

Bogdanović V., Đedović R. (2003): Testiranje i metode procene priplodne vrednosti simentalskih bikova. Savremeni trendovi u mlekarstvu, Zbornik radova, Zlatibor: 46-50.

Chladek G., Kucera J. (2000): An analysis of some factors affecting the milk production of cows sired by Montbeliard sires in the Czech Republic. Acta Universitatis Agriculturae et Silviculturae Mendelianae Brunensis, 48 (5): 21-26.

Đurđević R. (2001): Genetička analiza mlečnosti i reprodukcijskih svojstava krava simentalske rase. Doktorska disertacija. Poljoprivredni fakultet Novi Sad, 2001.

Đurđević R., Vidović V., Antov G., Latinović D. (2002): Genetička varijabilnost perzistencije laktacije krava simentalske rase. Biotechnology in Animal Husbandry, 18 (5-6): 9-15.

Fis s F.C., Wilton J.W. (1989): Effects of breeding system, cow weight and milk yield on reproductive performance in beef cattle. Journal of Animal Science, 67 (7): 1714-1721.

Gaydarska V., Krustev K., Simeonova S., Ivanov M. (2001): Influence of environmental and genetic factors on the milk yield and phenotypic and genotypic 
parameters of milk production in Black and White dairy cows in Bulgaria. Biotechnology in Animal Husbandry, 17 (1-2): 11-15.

Hansen L., Freeman A.E., Berger P.J. (1983): Variances, Repeatabilites and Age Adjustmens of Yield and Fertility in Dairy Cattle. Journal of Dairy Science, 66: 281-292.

Jovanovac S. (1987): Utjecaj sistematskih faktora okoline na mliječnost krava Holstein-Friesian pasmine. Znanost i praksa u poljoprivrednoj i prehrambenoj tehnologiji, 17 (3-4): 303-314.

Kucera J., Hyanek J., Miksik J., Cermak V. (1999): The influence of the season of parurition on milk performance in Czech Pied cattle. Czech Journal of Animal Science, 44 (8): 343-350.

Lin C.Y., Mc Allistek A.J., Batra T.R. (1988): Effects of early and late breeding of heifers on multiple lactation performance of dairy cows. Journal of Dairy Science, 71: 10.

Mchau K.W., Syrstad O. (1991): Production characteristics of Mpwapwa cattle. 2. Shape of the lactation curve. World Animal Review, 66: 49-54.

Michel A., Leuenberger H., Kunzi N. (1989): Optimales erstkalbealter fur gealpte rinder unterschiedlicher zuchtrichtung. Simentaler Fleckvieh, 6: 15-19.

Petrović M.D., Bogdanović V., Bogosavljević-Bošković Snežana, Rakonjac S., Đoković R., Petrović M. (2016): Uticaj fiksnih i kontinuelnih ambijentalnih faktora na proizvodnju 4\% mast-korigovanog mleka $\mathrm{u}$ prve tri laktacije kod krava simentalske rase. XXI Savetovanje o Biotehnologiji, Čačak, 11-12. Mart 2016. Zbornik radova, 21 (24): 525-533.

Panić J. (2005): Kvantitativno - genetička analiza svojstava mlečnosti krava simentalske rase. Poljoprivredni fakultet, Univerzitet u Novom Sadu -Magistarska teza.

Pantelić V., Skalicki Z., Petrović M.M., Aleksić S., Miščević B., Ostojić D. (2005): Phenotypic Variability of Milk Traits in Simmental Bull Dams. $8^{\text {th }}$ International Symposium Modern Trends In Livestock Production. Belgrade Zemun, Serbia and Montenegro, 5.-8.10.2005. Biotechnology in Animal Husbrandy, 21 (5-6): 31-34.

Perišić P. (1998): Reproduktivne i proizvodne osobine različitih genotipova krava simentalske rase. Magistarska teza, Poljoprivredni fakultet, Beograd-Zemun.

Perišić P., Skalicki Z., Petrović M.M., Mekić C., Đedović-Vidić R. (2002): Uticaj uzrasta pri prvoj oplodnji na proizvodne osobine krava simentalske rase. Savremena poljoprivreda, 51 (3-4): 97-99.

Petrović D.M., Bogdanović V., Petrović M.M., BogosavljevićBošković S. (2010): Uticaj paragenetskih faktora na proizvodnju $4 \%$ mastkorigovanog mleka u celim i standardnim laktacijama. XV savetovanje o biotehnologiji, Čačak, 26-27. mart 2010. Zbornik radova, 15 (17): 585-590.

Petrović D.M., Đoković R., Bogosavljević-Bošković S., Kurćubić V. (2006): Uticaj paragenetskih faktora na proizvodne osobine standardnih laktacija kod krava simentalske rase. Savremena poljoprivreda, 55 (1-2): 138-143.

Petrović D.M., Skalicki Z., Bogdanović V., Petrović M.M., Kurćubić V.(2005): The effect of paragenetic factors on performance traits in complete lactations in Simmental cows. $8^{\text {th }}$ International Symposium Modern Trends 
In Livestock Production Belgrade Zemun, Serbia and Montenegro, 5.-8. 10. 2005. Biotehenology In Animal Husbrandy, 21 (5-6): 7-12.

Petrović M.M., Lazarević R., Lazarević LJ., Aleksić S., Miščević B., Perković S. (1997): Proizvodni efekti selekcije aktivne populacije simentalskih goveda u Srbiji. Biotehnologija u stočarstvu, 13, (3-4): 57-64.

Petrović M.M., Sretenović Lj., Pantelić V., Aleksić S., Miščević B., Bogdanović V., Ostojić D., Petrović D.M. (2006): Results of the Application of the Technology of Genetic Improvement of Simmental Cattle Population in Serbia. Biotechnology in Animal Husbandry, 22 (1-2): 1-8.

Rychen M. (1999): A $6279 \mathrm{~kg}$ milk yield - where are the limits? SchweizerFleckvieh. 1999, (7): 26-39.

Saveli O. (1997): Effects of calving season on evaluation of the breeding value of dairy cattle. Book of Abstracts of the $48^{\text {th }}$ Annual Meeting of the European Association for Animal Production, Vienna, Austrija, 25-28 August: p. 225.

Singh D., Yadav A.S., Dhaka S.S. (2002): Studies on milk production profile attributes affected by environment and heredity in crossbred cattle. $7^{\text {th }}$ World Congress on Genetics Applied to Livestock Production, Montpellier, France: 1-4.

Stojić P., Katić M., Lazarević Lj., Latinović D., Trifunović G., Beskorovajni R., Brkić N. (1995): Ponovljivost dnevnih prinosa mleka tokom laktacije crno belih krava. Prvi Simpozijum za oplemenjivanje organizama sa međunarodnim učešćem. Vrnjačka Banja: 373-380.

Stojić P., Latinović D., Katić M., Lazarević Lj., Trifunović G., Beskorovajni R., Ćirić M. (1996): Značaj korekcije heterogenih varijansi u oceni priplodne vrednosti krava i bikova. Biotehnologija u stočarstvu, 12 (1-2): 2328.

Statsoft Inc. Statistica For Windows, Version 6.0, Computer program manual. Tulsa,: StatSoft Jnc., 1995. 
Acta Agriculturae Serbica, Vol. XXII, 43 (2017); 23-35

\title{
UTICAJ SISTEMATSKIH FAKTORA NA PROIZVODNJU 4\% MAST KORIGOVANOG MLEKA KOD KRAVA SIMENTALSKE RASE
}

\author{
Milun D. Petrovići ${ }^{1}$ Vladan Bogdanović ${ }^{2}$, Snežana Bogosavljević-Bošković ${ }^{1}$, \\ Radojica Đoković ${ }^{1}$, Simeon Rakonjac ${ }^{1}$, Miloš Ži. Petrović ${ }^{1}$, Vladimir \\ Dosković ${ }^{1}$ \\ ${ }^{1}$ Univerzitet u Kragujevcu, Agronomski fakultet u Čačku, Srbija \\ ${ }^{2}$ Univerzitet u Beogradu,Poljoprivredni fakultet, Zemun, Srbija
}

\section{Rezime}

Analiza uticaja sistematskih i kontinuelnih faktora okoline na proizvodnju 4\% mast-korigovanog mleka u celim i standardnim laktacijama kod 2805 krava simentalske rase izvršena je primenom opšteg linearnog modela. Od sistematskih odnosno fiksnih faktora analiziran je uticaj farme ili odgajivačkog područja, sezone telenja, godine i sezone rođenja, grupe laktacija i interakcije između godine i sezone rođenja, odgajivačkog područja i sezone telenja i odgajivačkog područja i grupe laktacija. Od kontinuelnih faktora posmatran je uticaj uzrasta pri prvoj oplodnji.

Uticaj odgajivačkog područja, grupe laktacija i sezone telenja na proizvodnju $4 \% \mathrm{MKM} \mathrm{u}$ celim i standardnim laktacijama bila je vrlo visoko značajna $(\mathrm{P}<0.001)$.

Interakcije fiksnih, odnosno sistematskih faktora, uključenih u model, kao što su interakcija između godine i sezone rođenja, zatim odgajivačkog područja i sezone telenja i farme i grupe laktacija, na proizvodnju 4\%MKM kako u celim tako i u standardnim laktacijama imale su vrlo visoko značajan uticaj $(\mathrm{P}<0.001)$.

Uzrast pri prvoj oplodnji, kao kontinuelni faktor, statistički vrlo visoko značajno $(\mathrm{P}<0.001)$ je uticao na proizvodnju $4 \%$ mast-korigovanog mleka i u celim i u standardnim laktacijama.

Primenjeni model za korekciju proizvodnje $4 \% \mathrm{MKM}$ u celim i standardnim laktacijama na dejstvo sistematskih faktora bio je vrlo visoko značajan $(\mathrm{P}<0.001)$. Udeo varijanse modela u ukupnoj varijansi kretao se od $15.93 \%$ kod proizvodnje 4\%MKM u celim laktacijama do $21.55 \%$ kod proizvodnje $4 \% \mathrm{MKM}$ u standardnim laktacijama. Dobijeni koeficijenti determinacije $\left(\mathrm{R}^{2}\right)$ kod proizvodnje $4 \% \mathrm{MKM} \mathrm{u}$ celim i standardnim laktacijama iznosili su 0.159 i 0.216.

Ključne reči: simentalska rasa, $4 \%$ mast-korigovano mleko, sistematski uticaji, koeficijent determinacije. 